\title{
PSYCHE
}

\begin{tabular}{lll}
\hline VOL. XLIX & MARCH-JUNE, 1942 & Nos. 1-2 \\
\hline
\end{tabular}

\section{A NEUROPTEROUS MYRMECOPHILE, NADIVA VALIDA ERICHS.}

\author{
BY NEAL A. WEBER
}

\section{University of North Dakota}

None of the insects of the Order Neuroptera seem to have been recorded as dwelling with ants in any degree of myrmecophily. This is hardly surprising in view of the predatory nature of these insects. The finding, therefore, of larvæ of a neuropteron living as symphiles with a common and widespread ant was quite unexpected.

While travelling up the Courantyne River, boundary between Surinam and British Guiana, as the guest of the British Boundary Commission, a brief stop was made at Wonotobo Falls July 13, 1936 in about $4^{\circ} 22^{\prime}$ N. Lat. Here in a small clearing in the virgin rain forest was a temporary depot of the Commission. Some of the medical stores were kept in a plywood Vanesta box of about one bushel capacity. In opening the box to take out quinine I found the box alive with the large and pugnacious ant, Camponotus (Myrmothrix) abdominalis (Fabr.). The cover was sufficiently warped to permit the ingress and egress of the ants. While collecting some of the ants a few small, active insect larvæ of an unusual blue in color were noticed scurrying about among the piles of ant eggs, larvæ and pupæ lying openly on the floor of the box. Some of the ants carried off these blue larvæ in the same manner as they carried their own brood, securely held between the mandibles, and with equal care. The blue larvæ were nearly as active as the ant workers and some ran off by themselves. 
There was definitely no hostility between the ants and the guest larvæ; rather the latter seemed to be treated as ant brood.

Unfortunately I had to continue my journey upriver immediately and had time only to place a few of the blue larvæ in a small vial. Strenuous travelling up several hundred miles of rapids and falls prevented study of the material. One larva pupated during the journey and July 28 an imago emerged. Mr. Nathan Banks has kindly determined this as Nadiva valida Erichs. (Chrysopidæ) with the note that the

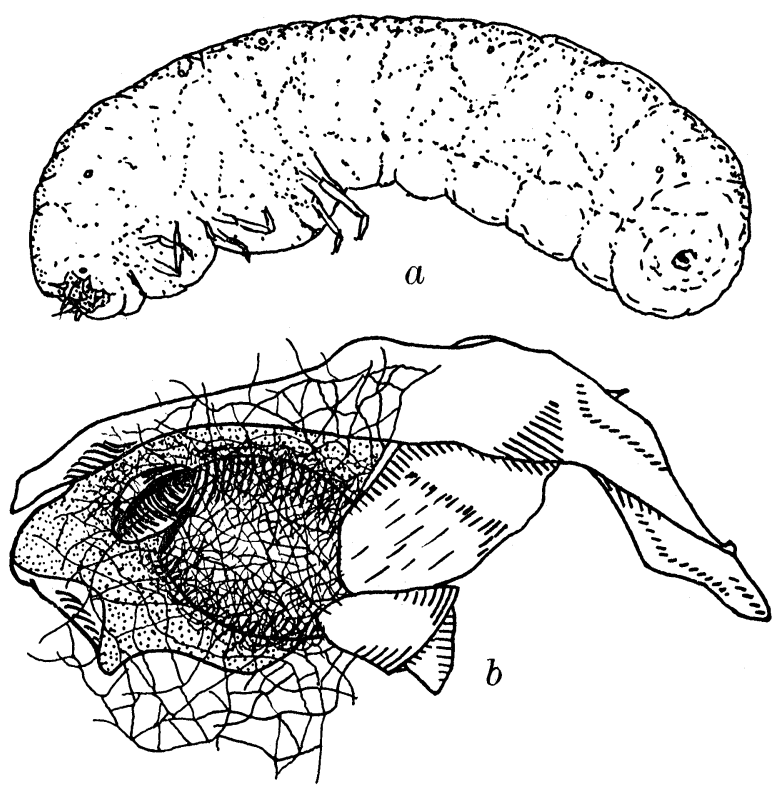

Fig. 1. $a$, Larva of Nadiva valida Erichs; $b$, Pupal case of same.

species "was described from the United States but known also from Brazil. It belongs to a peculiar group, the body being broad and heavy; and the venation not as much specialized and inconstant. Allied forms are mostly in South Brazil, Argentina and Bolivia." The larva and neat cocoon are figured below.

A large larva after preservation was $10.5 \times 5 \mathrm{~mm}$., the extended and dried pupal envelope $10.5 \mathrm{~mm}$. and the ellipti- 
cal cocoon $5.5 \times 7 \mathrm{~mm}$. The latter was a light straw yellow in color and firmly affixed by yellow threads to crumpled blue paper which covered absorbent cotton. From an even horizontal break or cut in the case one millimeter from an end the imago had emerged.

Camponotus abdominalis is widespread and abundant in the Neotropical Region. The colonies are often very populous while the workers and soldiers are among the most aggressive of ants, the latter inflicting painful bites. The present nesting site is not unusual. I found these ants nesting in Trinidad in such places as old cacao pods, Nasutitermes nests (termite-inhabited or not), a disused teapot, a writing desk and a gentleman's cabbage walking stick.

There are some aspects of the relationships between this ant and the Nadiva larvæ which would repay study and which could not be worked out in view of the circumstances described above. How were the guests adopted? How do they obtain food? Perhaps, after in some manner acquiring the ant nest odor, the larvæ were adopted. Or were the eggs laid in the ant nest? The young larvæ might have been active and elusive enough to escape the first attacks of the ants and would soon acquire the nest odor. In view of the known predatory habits of Neuroptera larvæ it would not be surprising to find that they fed upon the brood of their hosts. The larvæ are covered with short, stout hairs but with nothing resembling trichomes so what they could give the ants in return is unknown. 

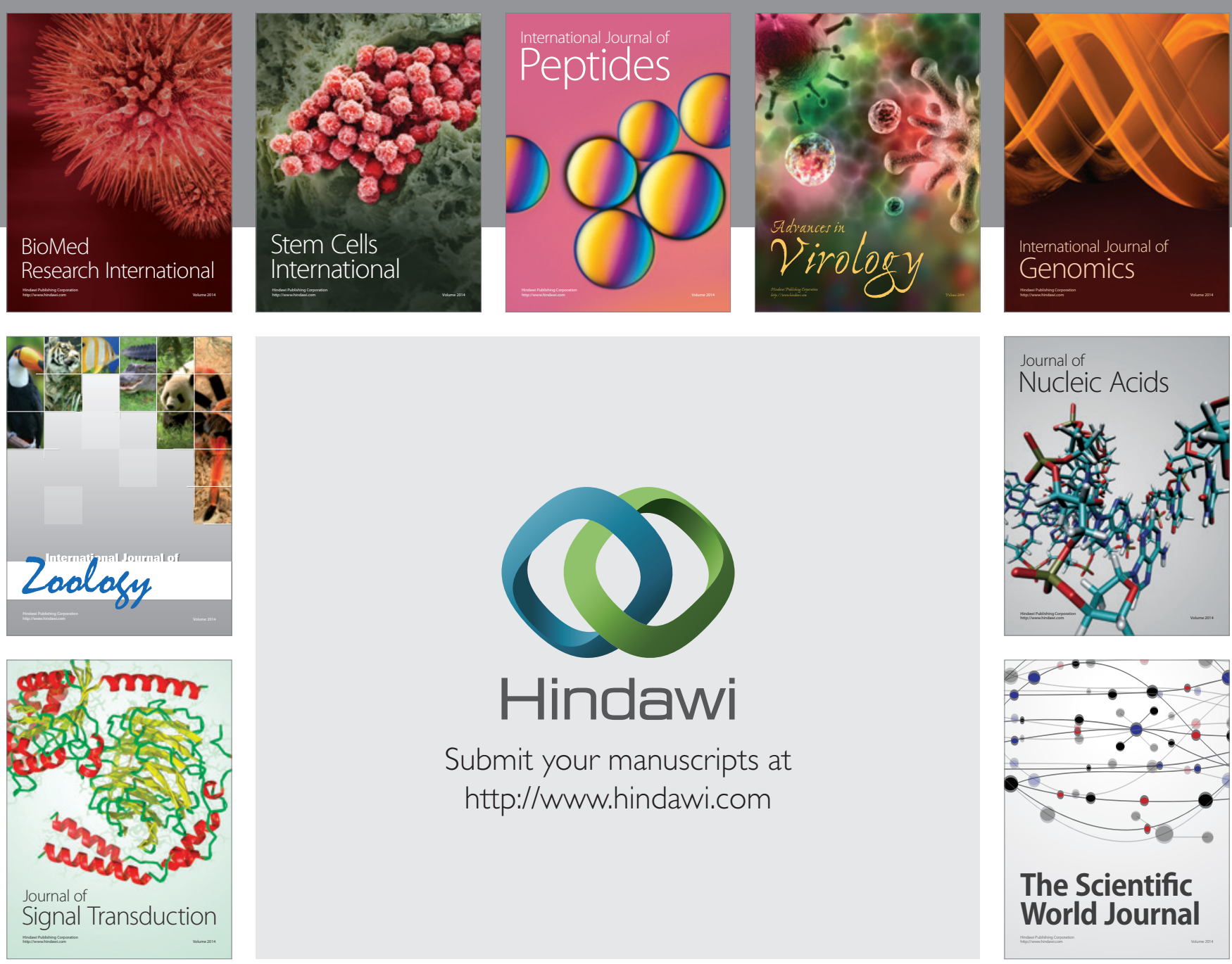

Submit your manuscripts at

http://www.hindawi.com
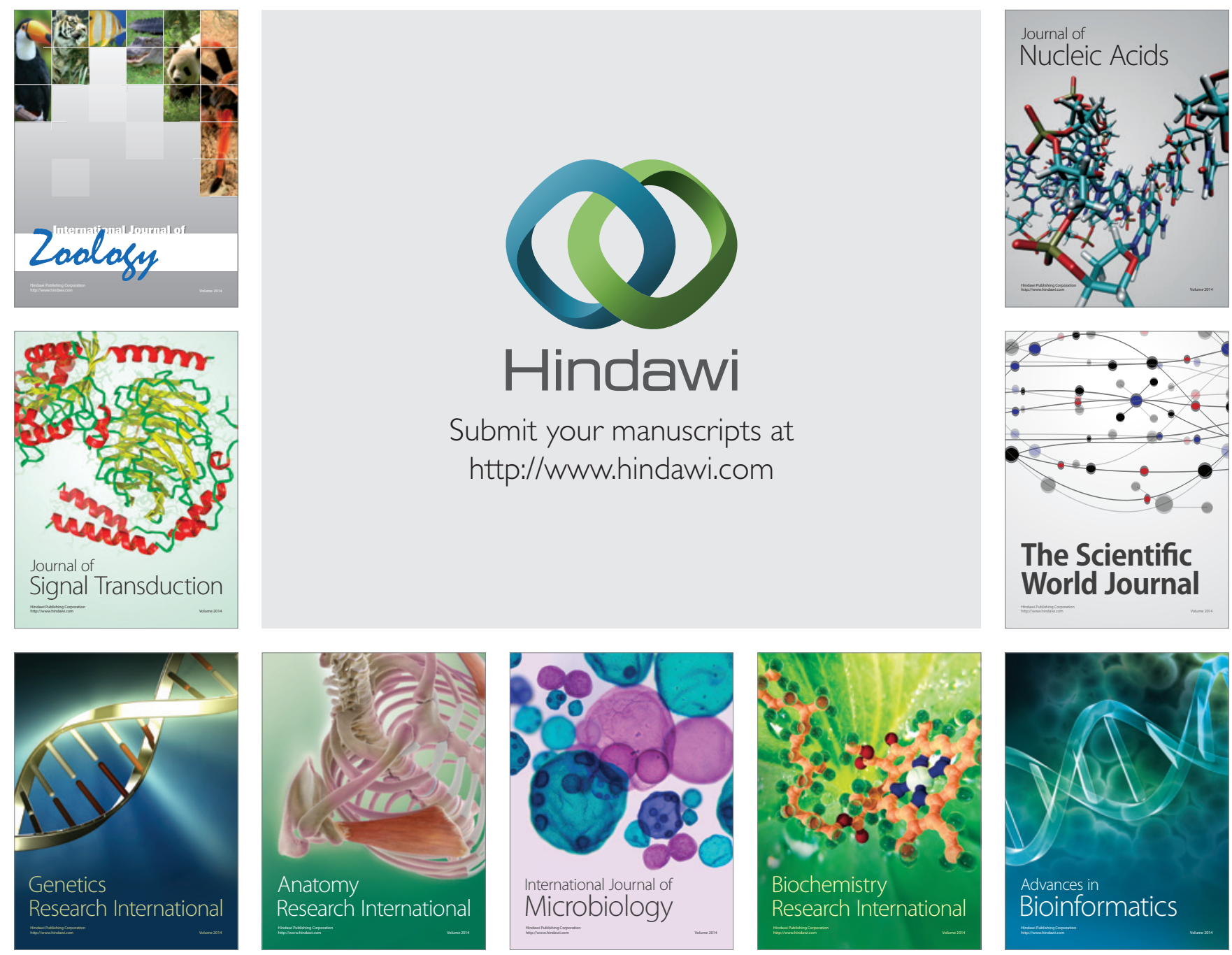

The Scientific World Journal
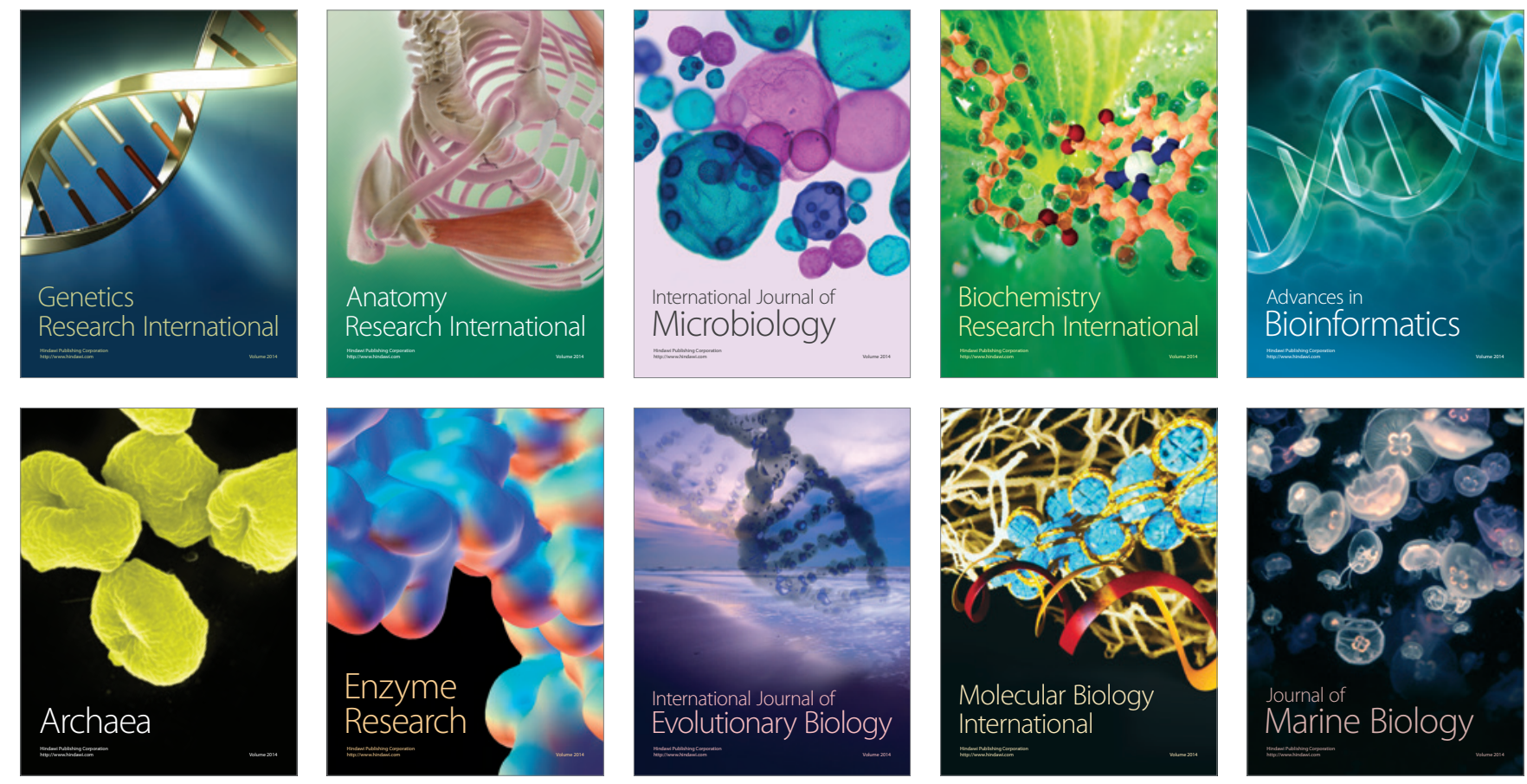